NOTE

\title{
Measuring sublethal impacts of pollution on reproductive output of marine Crustacea
}

\author{
Alex T. Ford ${ }^{1, *}$, Teresa F. Fernandes ${ }^{1}$, Sebastien A. Rider ${ }^{1}$, Paul A. Read ${ }^{1}$, \\ Craig D. Robinson' ${ }^{2}$, Ian M. Davies ${ }^{2}$ \\ ${ }^{1}$ School of Life Sciences, Napier University, 10 Colinton Road, Edinburgh EH10 5DT, UK \\ ${ }^{2}$ Fisheries Research Services Marine Laboratory, PO Box 101, 375 Victoria Road, Aberdeen AB11 9DB, UK
}

\begin{abstract}
Fecundity and fertility in the amphipod Echinogammarus marinus (Leach) were investigated at 2 industrially contaminated sites and compared with data from 2 reference sites. Although some studies have used amphipod fecundity or fertility as biomarkers of environmental perturbation, there has been very little standardisation with regard to the endpoints quantified. Mean brood size, brood size normalised to female weight, and embryos in early and late stages of development have been utilised as measures of amphipod fecundity and fertility. The present study examined the effectiveness of all these measures as biomarkers of pollution. The results suggest that different interpretations can be derived depending on the measure used to express fecundity or fertility. Compared with impacted sites, only reference sites had larger broods normalised to female weight. Separating early- and late-egg developmental stages provided additional information as to whether initial fecundity, or relative fertility, was being affected compared with pooled data (all embryo stages). Both reference sites produced more eggs in early stages of development than impacted sites, but only 1 impacted site had fewer embryo numbers at later stages of development. These results indicate that separating embryo stages in field monitoring or laboratory studies provides more effective indicators of reproductive endpoints, and misinterpretations may result if the loss of eggs and/or embryos from the brood chamber is not taken into consideration.
\end{abstract}

KEY WORDS: Echinogammarus marinus - Amphipoda - Reproduction - Fecundity - Fertility · Embryonic development $\cdot$ Biomarker $\cdot$ Pollution

Resale or republication not permitted without written consent of the publisher

\section{INTRODUCTION}

Amphipod models are used extensively in lethal (USEPA 1994, ASTM 1997, Bat \& Raffaelli 1998, Roddie \& Thain 2002) and sublethal toxicity tests employing a variety of endpoints, including growth, reproduction, behaviour and morphology (Malbouisson et al. 1995, Nelson \& Brunson 1995, Blockwell et al. 1996, Gray et al. 1998, Ingersoll et al. 1998). These endpoints can sometimes demonstrate effects at population and community levels that may be occurring at more marginally contaminated sites in the field (Ingersoll et al. 1998). Whilst there have been many studies detailing sublethal effects of contaminants on amphipods, few have considered effects upon fecundity at both individual and population levels. Moreover, studies to date using embryo or neonate numbers as measures of fecundity may actually be measuring relative fertility.

Reproductive output can be expressed in various ways at both the individual and the population levels. Examples include mean brood size, mean brood size normalised to female weight, number of embryos per female or surviving female, number of embryos/ neonates per female or surviving female, or number of gravid females per female or surviving female. 
Many field and laboratory studies have demonstrated that fecundity/fertility can be affected by a variety of different contaminants (Sundelin 1983, 1984, 1988, 1989, Borowsky et al. 1993, 1997, Eriksson et al. 1996, Sundelin \& Eriksson 1998, Zulkosky et al. 2002).

Whilst investigating fecundity in normal and intersex specimens of the amphipod Echinogammarus marinus (Leach), Ford et al. (2003) showed that female intersex specimens produce fewer eggs than normal females. Dick et al. (1998) reported that females of the amphipod Crangonyx pseudogracilis would selectively eject non-viable eggs when cycling eggs within the brood chamber. Furthermore, reports suggest that both intersex amphipods (Bulnheim 1965), and amphipods from polluted sites (Borowsky et al. 1997) display abnormal brood plates, possibly making eggs liable to escape the brood chamber. Considering the possibility that intersex specimens display abnormal brood plates and may be more likely to produce non-viable eggs, Ford et al. (2003) hypothesised that comparison of the mean number of embryos at early and late stages of development from a population might provide a measure of the loss of embryos from a brood. They reported that intersex specimens showed approximately $30 \%$ reduction in mean brood size between early and late stages of development compared with $20 \%$ in normal specimens. Ford et al. (2003) suggested that such embryo stage assessment might be applied to ecotoxicological field studies, whereby individuals from contaminated sites might display greater decreases in embryo numbers between early and late stages of development than individuals from reference sites.

In this study, we compare the fecundity of the amphipod Echinogammarus marinus from 2 reference sites (Dunbar and Loch Fleet), 1 intermediate site (Torry Bay), and 1 contaminated site (Inverkeithing Bay) on the east coast of Scotland. Sites were chosen on the basis of water quality and the availability of E. marinus. Both Dunbar and Loch Fleet are categorised as Class A (excellent) under the Scottish Environment Protection Agency (SEPA) classification scheme for estuaries, whilst Torry Bay and Inverkeithing are categorised as Class B (good) and C (unsatisfactory) respectively. Both Torry and Inverkeithing Bay have been recently upgraded from Class $\mathrm{C}$ (unsatisfactory) and Class D (seriously polluted) respectively, due to improved water quality (SEPA pers. comm.). Torry Bay is situated in the mid-region of the Forth Estuary and has been subject to petrochemical discharges since the 1920s (McLusky \& Martins 1998). Inverkeithing is a semi-enclosed bay with a shipbreaker's yard on the south shore and a paper mill on the north shore, and is characterised by elevated levels of PCBs, heavy metals and paper fibres in the sediments (SEPA 2000).
Echinogammarus marinus is a highly abundant amphipod in marine and estuarine intertidal regions along NE Atlantic coastlines, stretching from Norway to southern Portugal (Lincoln 1979). E. marinus is relatively large, with males reaching up to $25 \mathrm{~mm}$ in length and females up to $20 \mathrm{~mm}$. E. marinus females produce approximately 20 eggs per brood (Cheng 1942) that are extruded in a brood chamber (marsupium). As with many amphipods, males and females form pre-copula pairs, whereby the males hold on to females until they moult and fertilisation can take place.

The aim of this study was to assess the effects of 2 industrially contaminated sites on reproductive parameters of Echinogammarus marinus by comparison with amphipods at reference sites. Observations of fecundity and relative fertility are discussed in relation to environmental contamination. Furthermore, the relative merits of assessing different embryonic stages of E. marinus and other species as biomarkers in reproductive toxicity experiments and monitoring programmes are discussed.

\section{MATERIALS AND METHODS}

Specimens of Echinogammarus marinus were collected from underneath stones and seaweed at the 4 field sites between February and July 2002 (Table 1) and taken back to the laboratory for identification according to Lincoln (1979: synonym Chaetogammarus). All specimens were anaesthetised with carbonated seawater, sexed, blotted dry with tissue paper and then weighed. Embryos were removed from all gravid females using a fine pipette. These were counted and categorised according to 6 embryonic stages described by Sheader \& Chia (1970) (Fig. 1). The term 'embryo' is used synonimously with egg throughout this manuscript as 'early'-stage embryos may also include unfertilised eggs. Brood sizes were recorded and either

Table 1. Echinogammarus marinus. Sampling dates and location of total and gravid individuals collected during survey

\begin{tabular}{|c|c|c|c|c|}
\hline $\begin{array}{l}\text { Sampling } \\
\text { site }\end{array}$ & Location & $\begin{array}{c}\text { Sampling } \\
\text { date }(\mathrm{d} / \mathrm{mo} / \mathrm{yr})\end{array}$ & Total & $\begin{array}{l}\text { Gravid } \\
\text { females }\end{array}$ \\
\hline $\begin{array}{l}\text { Dunbar } \\
\text { (Belhaven Bay) }\end{array}$ & $\begin{array}{l}56^{\circ} 00^{\prime} 11.7^{\prime \prime} \mathrm{N} \\
2^{\circ} 32^{\prime} 29.4^{\prime \prime} \mathrm{W}\end{array}$ & $\begin{array}{l}\mathrm{N}, 12 / 03 / 02 \\
20 / 03 / 02 \\
19 / 04 / 02 \\
02 / 07 / 02\end{array}$ & $\begin{array}{l}300 \\
300 \\
275 \\
241\end{array}$ & $\begin{array}{r}22 \\
46 \\
127 \\
81\end{array}$ \\
\hline Loch Fleet & $\begin{array}{l}56^{\circ} 05^{\prime} 35.7^{\prime \prime} \mathrm{N}, \\
3^{\circ} 09^{\prime} 29.0^{\prime \prime} \mathrm{W}\end{array}$ & $\begin{array}{l}\text { N, } 15 / 04 / 02 \\
23 / 06 / 02\end{array}$ & $\begin{array}{l}300 \\
300\end{array}$ & $\begin{array}{r}115 \\
87\end{array}$ \\
\hline Torry Bay & $\begin{array}{l}56^{\circ} 03^{\prime} 26.4^{\prime \prime} \mathrm{N}, \\
3^{\circ} 34^{\prime} 24.9^{\prime \prime} \mathrm{W}\end{array}$ & $\begin{array}{l}\mathrm{N}, \quad 14 / 03 / 02 \\
04 / 07 / 02\end{array}$ & $\begin{array}{l}300 \\
275\end{array}$ & $\begin{array}{l}124 \\
124\end{array}$ \\
\hline $\begin{array}{l}\text { Inverkeithing } \\
\text { Bay }\end{array}$ & $\begin{array}{l}56^{\circ} 01^{\prime} 38.5^{\prime \prime} \mathrm{N}, \\
3^{\circ} 34^{\prime} 24.9^{\prime \prime} \mathrm{W}\end{array}$ & $\begin{array}{l}\text { J, } 18 / 03 / 02 \\
27 / 07 / 02\end{array}$ & $\begin{array}{l}300 \\
300\end{array}$ & $\begin{array}{l}170 \\
114\end{array}$ \\
\hline
\end{tabular}


Fig. 1. Echinogammarus marinus. Stages of embryonic development (after Sheader \& Chia 1970). (a) Early cleavage stages; (b) development of germinal disc/appearance of dorsal organ; (c) formation of caudal furrow and appearance of appendage rudiments; (d) segmentation of all appendages, reduction of dorsal organ, development of optic rudiments, widening of caudal furrow; (e) appearance of red pigment spots on eye rudiments, heart beating, muscular movement of gut (f) hatched juveniles inside brood chamber
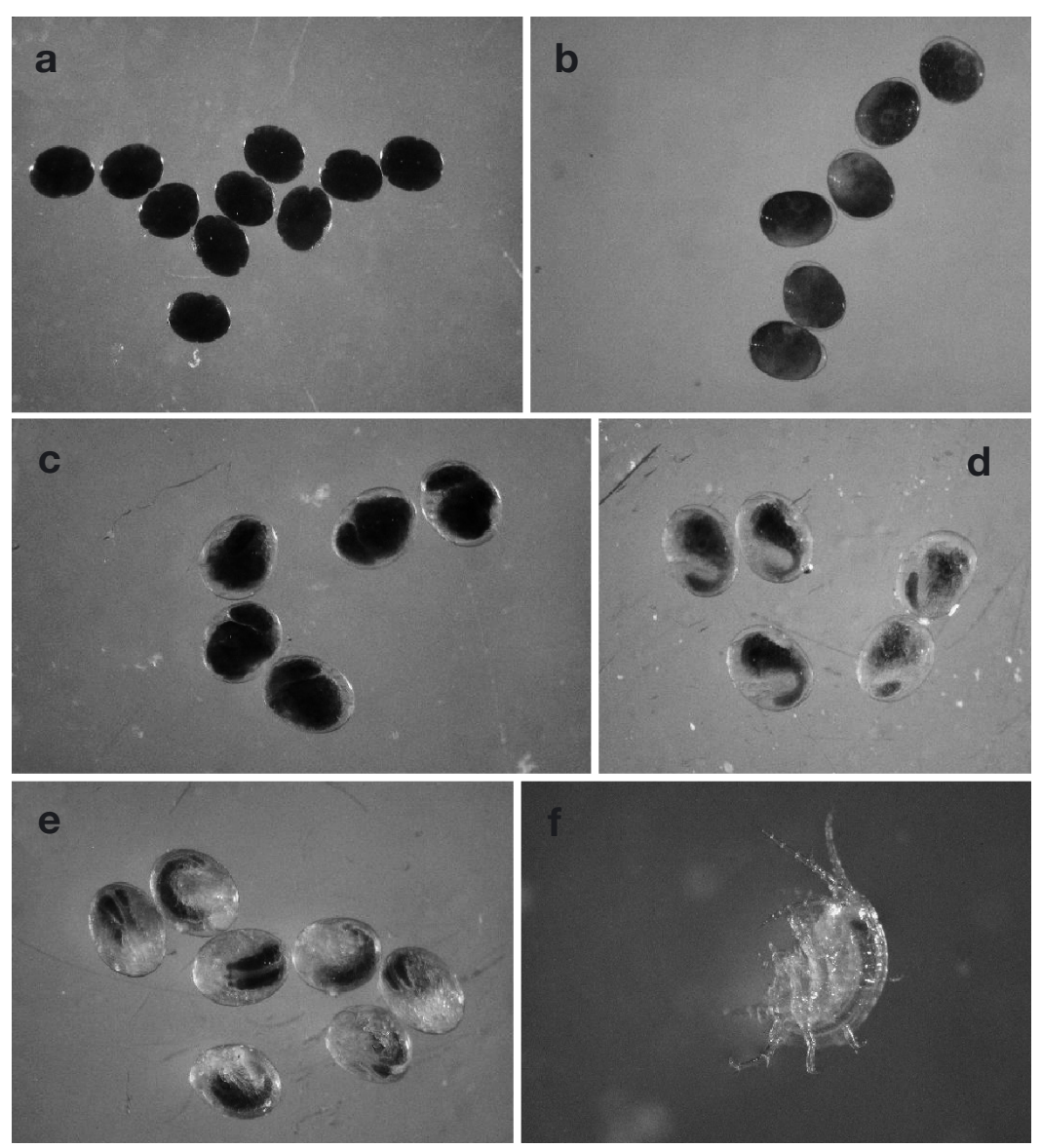

expressed as embryos per female, or embryos per female normalised for weight, the latter because of the recognised correlations between female size and brood size (Cheng 1942, Skadsheim 1984, Adams 1989, Glazier 2000, Ford et al. 2003). All embryos were classified within $2 \mathrm{~d}$ of collection to prevent further development in conditions not representative of those in the field. Specimens were stored at $10^{\circ} \mathrm{C}$ during processing to further reduce embryonic development.

All monthly data for each site were pooled for statistical analyses, which were carried out using SPSS for Windows (Version 10). Where normality of data was not observed (e.g. mean brood-size data), simple square-root transformation was conducted and normality was achieved. Homogeneity of variance could not be achieved, and so Tamhane's multiple comparison tests (SPSS 2001), whereby homogeneity is not assumed, were performed.

\section{RESULTS}

A total of 2891 Echinogammarus marinus were examined during this survey (Table 1). Fig. 2 shows that the mean numbers of embryos decreased with increasing developmental stage (except Stage 1), with the greatest decrease occurring between Stages 3 and 4. For this reason, embryonic stages were reclassified according to Ford et al. (2003) as early (Stages 1 to 3) and late (Stages 4 and 5).

The mean number of embryos per female $( \pm \mathrm{SD})$ decreased in the order Dunbar, Torry Bay, Inverkeithing and Loch Fleet $(24.8 \pm 13.88,22 \pm 10.29,17.3 \pm 10.83$ and $17 \pm 8.38$, respectively; Fig. 3a). The mean number of embryos ( $\pm 2 \mathrm{SE}$ ) normalised for weight $(\mathrm{mg})$ decreased in the order Dunbar, Loch Fleet, Torry Bay and Inverkeithing $(0.41 \pm 0.01,0.39 \pm 0.01,0.36 \pm 0.01$ and $0.31 \pm 0.01$, respectively; Fig. $3 \mathrm{~b}$ ). The mean female weight $( \pm \mathrm{SD})$ for each site decreased in the order Torry Bay, Inverkeithing, Dunbar and Loch Fleet (57.1 \pm 21.1 , $56.7 \pm 21.3,51.1 \pm 20.1$ and $39.0 \pm 16.6 \mathrm{mg}$, respectively)

Brood-size data (square-root-transformed) for each site were compared, revealing significant differences between sites (ANOVA, $F_{3,1006}=28.772 ; \mathrm{p}<0.001$ ). Multiple comparison tests revealed significant differences (Tamhane's test $\mathrm{p}<0.001$; Fig. 3a) between each site, except between Inverkeithing and Loch Fleet, and between Torry Bay and Dunbar. 


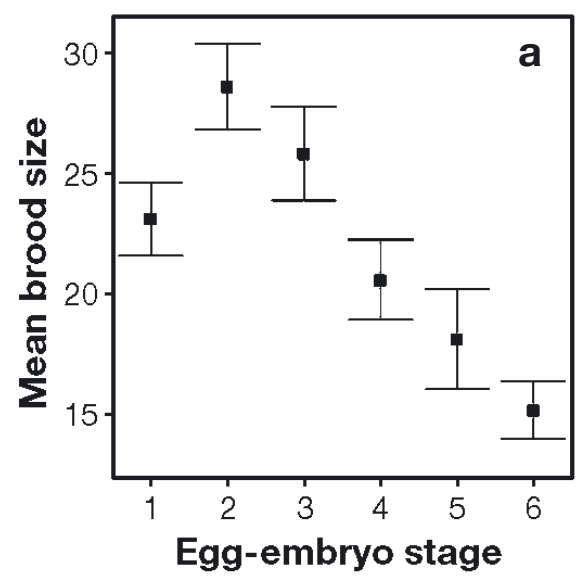

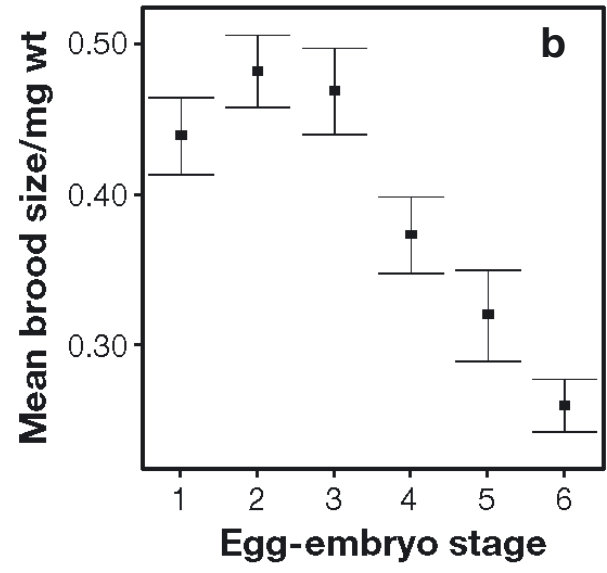

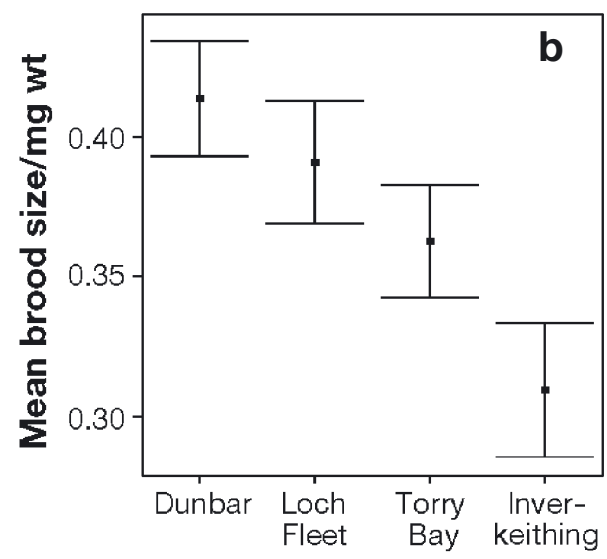

Fig. 2. Echinogammarus marinus. (a) Mean ( \pm 2 SE) number of eggs/embryos (brood size) at each stage of development (pooled for all sites); (b) mean $( \pm 2 \mathrm{SE})$ brood size per mg maternal weight at 6 stages of embryonic development (pooled for all sites)

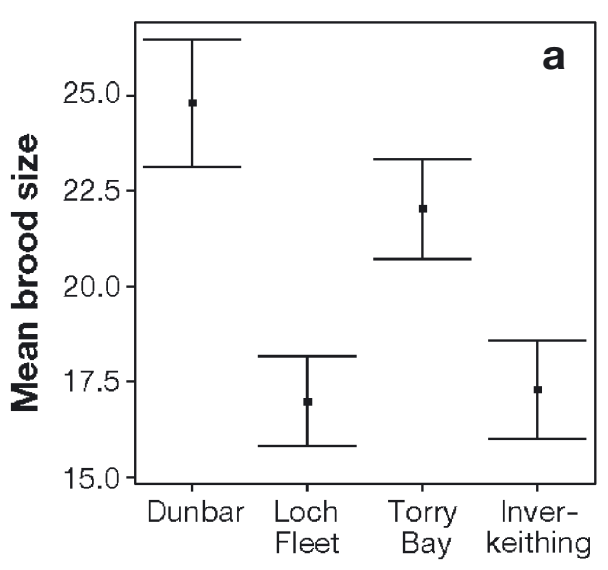

Embryo numbers normalised to weight (Fig. 3b) revealed different patterns in mean brood size per female. Significant differences were found when comparing all sites (ANOVA, $F_{3,1006}=18.121 ; \mathrm{p}<0.001$ ). All sites differed significantly (Tamhane's test $\mathrm{p}<0.01$ ) from each other, apart from Dunbar and Loch Fleet, and Loch Fleet and Torry Bay.

When comparing early and late stages of development, Stages 1-3 and 4-5 were pooled and classified as early and late, respectively. We used 2-factor analysis of covariance (ANCOVA) to compare the different sites and stages of development (early and late), with weight as a covariable. Significant differences were observed between sites, developmental stages and the covariable, weight (ANCOVA, $F_{1,720}=16.24, F_{1,720}=$ 22.81 and $F_{3,720}=234.94, \mathrm{p}<0.001$, respectively, Fig. 4). There was no significant interaction between site and developmental stage $(\mathrm{p}=0.159)$.

Fig. 5a shows the mean brood sizes $( \pm 2 \mathrm{SE})$ of females carrying embryos in early stages of development (normalised for weight). More embryos in early stages of development were seen at reference sites than at impacted sites $(0.41 \pm 0.01$ and $0.41 \pm 0.02$ late stage embryos per maternal weight for Torry Bay and Inverkeithing, respectively). ANOVA revealed significant differences between sites (ANOVA, $F_{3,490}=6.562$; $\mathrm{p}<0.001)$. No significant differences were observed between the 2 reference sites and the 2 polluted sites, respectively (Tamhane's test $\mathrm{p}>0.05$ ). Torry Bay produced significantly fewer embryos than the 2 reference sites ( $p<0.001)$, and whilst Inverkeithing Bay specimens had lower numbers of embryos in early stages of development than the 2 reference sites (Dunbar and Loch Fleet), these differences were not significant at the $95 \%$ level $(p=0.076$ and $p=0.097$, respectively).

The 2 reference sites similarly had a greater mean number of later-stage embryos $(0.39 \pm 0.02$ and $0.41 \pm$ 0.01 embryos per maternal weight for Dunbar \& Loch Fleet, respectively) than the 2 contaminated sites $(0.37 \pm 0.03$ and $0.29 \pm 0.02$ embryos per maternal weight for Torry Bay and Inverkeithing, respectively, Fig. 5b). 

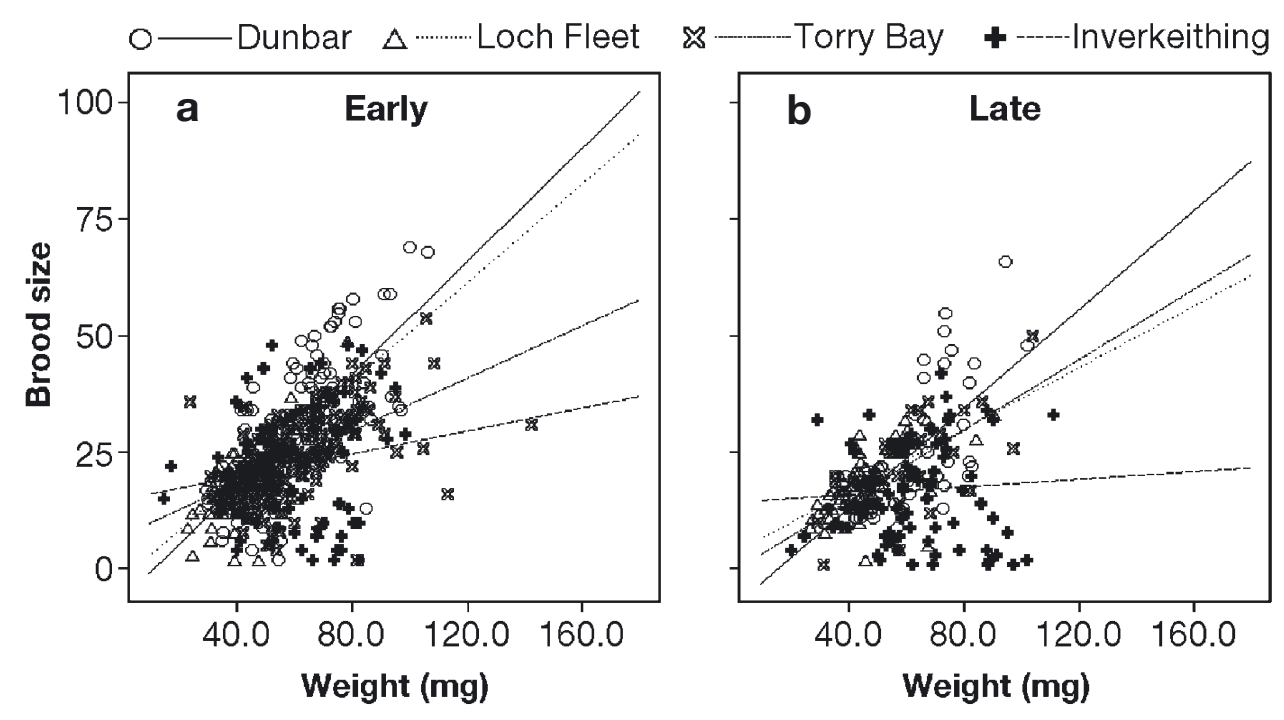

Fig. 4. Echinogammarus marinus. Comparison of brood size (no. of eggs/embryos) at reference and polluted sites in (a) early and (b) late stages of development, plotted against maternal weight
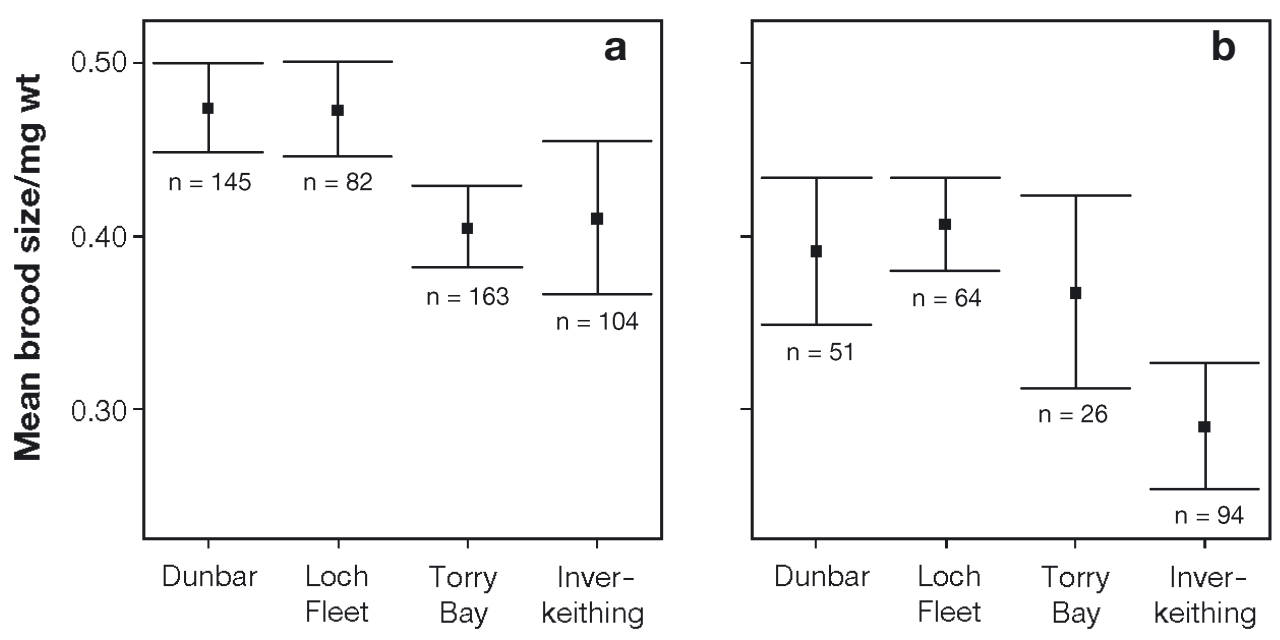

Fig. 5. Echinogammarus marinus. Mean $( \pm 2 \mathrm{SE}$ ) brood size at different embryonic stages from 2 reference sites (Dunbar and Loch Fleet) and 2 polluted sites (Torry Bay and Inverkeithing). Mean number of embryos per mg maternal weight in (a) early and (b) late stages of development

ANOVA indicated significant differences between sites when comparing embryos in late stages of development (ANOVA, $\left.F_{3,231}=9.272 ; \mathrm{p}<0.05\right)$. No significant differences were found between Dunbar, Loch Fleet, and Torry Bay. Inverkeithing (polluted) had significantly fewer embryos in later stages of development than the 2 reference sites (Tamhane's test $\mathrm{p}<0.01$ ).

\section{DISCUSSION}

Reproductive gametes (and zygotes) are usually more susceptible to toxicants than adults, especially organisms that undergo external fertilisation (Connell et al. 1999). Furthermore, species survival depends ultimately on reproductive success and quality of off- spring. For this reason, reproductive variables are sometimes considered more direct markers of significant toxicological effects.

Fecundity, in the strictest sense of the word, means 'the number of eggs/gametes produced by an individual', whereas fertility can be considered as 'the number of viable offspring per female'. Ford et al. (2003) hypothesised that comparison of embryo numbers at early and late stages of development might detect embryolevel effects of contaminants. Differences in fecundity versus fertility might therefore be a useful biomarker of pollution. Moreover, measuring both fecundity and fertility separately may provide useful insights into the mechanism of effect in various contaminants, i.e. whether a pollutant is having an effect on a developing gonad within a parent or a toxic effect on progeny. 
In this study, no apparent differences were found in the mean brood size at impacted and reference locations when maternal weight was not taken into consideration. However, when normalised to weight, the mean brood size separated in a decreasing order from the 2 reference sites (Dunbar and Loch Fleet) followed by the intermediate site (Torry Bay) and the most contaminated site (Inverkeithing), suggesting that fecundity and/or fertility may be affected by the contaminants at the polluted sites.

The mean weight of the females in the populations was greater at the impacted sites than at the reference sites during the period of this study. Apart from a few exceptions (e.g. Gammarus duebeni: Cheng 1942, Dunn \& McCabe 1995), there are strong correlations between length/weight variables and fecundity in many amphipod species (Cheng 1942, Skadsheim 1984, Adams 1989, Glazier 2000, Ford et al. 2003).

Categorising embryonic development into 6 stages according to Sheader \& Chia (1970) revealed a clear decrease in the mean number of embryos between Stages 3 and 4 . The lower mean brood size observed at Stage 1 compared with Stage 2 is probably a reflection of the relatively short period that eggs spend at this stage of development ( $1 \mathrm{~d}$ compared with $7 \mathrm{~d}$ spent at Stages 2 and 3; Lawrence \& Poulter 2001, A. Ford unpubl. data). For this reason, the data were then grouped so that Stages 1 to 3 were classified as 'early' stage embryos, and Stages 4 and 5 as 'late' stage embryos. This reduced the variance of the data and increased the statistical power of the analysis. Stage 6 (hatched) was not considered due to varying emergence times from the marsupium.

Embryo-stage assessment, as used in this study, may provide interesting insight into the differing sensitivity of embryonic stages. By using the same initial embryonic classification, Lawrence \& Poulter (2001) reported that embryos exposed to a variety of contaminants in vitro were mostly affected during Stages 2 to 4 . Quantifying embryo loss may also prove useful in assessing parental behaviour in some egg-brooding crustaceans, whereby there may be active ejection of non-viable/abnormal eggs or embryos. Whilst it is not clear whether the embryo loss observed in this study was entirely through active ejection or passive loss, it seems possible that this extraparental care may be more common throughout marine brooding crustaceans, such as Amphipoda.

Females at both reference sites carried approximately $13 \%$ more eggs in early embryonic stages than females at the contaminated sites, suggesting that pollution might be affecting fecundity (i.e. the number of eggs produced) directly. However, comparisons of the embryos in late stages of development revealed a different pattern from that of early stage embryos. There were no significant differences between the 2 reference sites and Torry Bay, whilst all 3 of these sites had signifi- cantly more embryos reaching later stages of development than Inverkeithing $(25,30$ and $22 \%$ for Dunbar, Loch Fleet and Torry Bay, respectively). Therefore fertility and embryonic development, as well as fecundity, may be affected at the most contaminated site. Increased contaminants at Inverkeithing may not only have affected ovary maturation, and hence egg quality/oocyte development, but also embryonic survival at sensitive life stages, as demonstrated through increased embryo loss. Although, as suggested earlier, this may be also a consequence of passive brood loss through abnormal brood plates. There were, in the current study, a few broods at Inverkeithing with irregularly developing embryos, suggesting toxic/endocrine mediated effects; however, these were not quantified.

A variety of contaminants have been shown to affect fecundity, egg viability and embryonic development in amphipods, including oil associated pollutants (Baden 1990, Lawrence \& Poulter 2001), PCBs (Borowsky et al. 1997), heavy metals (Sundelin 1983, Conradi \& Depledge 1998, Lawrence \& Poulter 2001), and pulpmill effluent (Eriksson et al. 1996).

The results from this study raise some important questions with regard to reproductive endpoints in crustacean models used in toxicity studies and environmental monitoring. By using slightly different reproductive variables relating to egg and/or embryo numbers, different interpretations of results can be derived, and thus there is a need to standardise methodology further. A number of published studies do not take differences in maternal weights into account and, furthermore, some studies have failed to differentiate between embryonic stages, which resulted in misleading conclusions.

Failure to take into account the drop in the mean brood size between early and late stages of development may similarly lead to underestimation of initial fecundity. For example, in the current study, approximately $30 \%$ difference was observed between early and late stages of development at Inverkeithing. Such large differences may also lead to misinterpretation as to whether initial fecundity or fertility is being affected, which may result in a misleading assessment of the causal mechanisms involved. Ford et al. (2003) observed reduced fecundity in intersex female Echinogammarus marinus, which was thought could be partly due to the inclusion of testicular tissue observed within the ovary and possibly reduced egg quality.

This study has confirmed that fecundity, embryonic development and fertility can be useful and practical endpoints in ecotoxicology. Furthermore, by differentiating between early and late stages of development, a clearer indication can be obtained as to whether fecundity or fertility might be affected. This methodology may prove transferable to other species that produce 
relatively few numbers of eggs with clearly defined and quantifiable embryonic development stages. However, the correlation between maternal size and egg production and seasonal patterns must be taken into account.

\section{LITERATURE CITED}

Adams J (1989) Natural selection and parental ability to vary resource partitioning amongst offspring? Oikos 56:135-137 ASTM (American Society for Testing \& Materials) (1997) Standard guide for conducting 10-day static sediment toxicity tests with marine and estuarine amphipods. E $1367-$ 92. In: Annual book of ASTM standards, Vol 11.05. American Society for Testing \& Materials, Philadelphia, p 731-756

Baden SP (1990) The cryptofauna of Zostera marina (L): abundance, biomass and population dynamics. Neth J Sea Res 27:81-92

Bat L, Raffaelli D (1998) Sediment toxicity testing: a bioassay approach using the amphipod Corophium volutator and the polychaete Arenicola marina. J Exp Mar Biol Ecol 226: 217-239

Blockwell SJ, Pascoe D, Taylor EJ (1996) Effects of lindane on the growth of the freshwater amphipod Gammarus pulex (L.). Chemosphere 32:1795-1803

Borowsky B, Aitken-Ander P, Tanacredi JT (1993) The effects of low doses of waste crankcase oil on Melita nitida Smith (Crustacea: Amphipoda). J Exp Mar Biol Ecol 166:39-46

Borowsky B, Aitken-Ander P, Tanacredi JT (1997) Changes in reproductive morphology and physiology observed in the amphipod crustacean, Melita nitida Smith, maintained in the laboratory on polluted estuarine sediments. J Exp Mar Biol Ecol 214:85-95

Bulnheim HP (1965) Untersuchungen über Intersexualität bei Gammarus duebeni (Crustacea, Amphipoda). Helgoländer Wiss Meersunters 12:349-394

Cheng C (1942) On the fecundity of some gammarids. J Mar Biol Assoc UK 25:467-475

Connell D, Lam P, Richardson B, Wu R (1999) Introduction to ecotoxicology. Blackwell Science, Oxford

Conradi M, Depledge MH (1998) Population responces of the marine amphipod Corophium volutator (Pallas, 1766) to copper. Aquat Toxic (Amst) 44:31-45

Dick JTA, Faloon SE, Elwood RW (1998) Active brood care in an amphipod: influences of embryonic development, temperature and oxygen. Anim Behav 56:663-672

Dunn AM, McCabe J (1995) Resource allocation to young: seasonal patterns within and between Gammarus duebeni populations. Oikos 73:199-202

Eriksson AK, Sundelin B, Broman D, Näf C (1996) Effects on Monoporeia affinis of HPLC-fractionated extracts of bottom sediments from a pulp mill recipient. In: Servos MR, Munkittrich KR, Carey JH, Van Der Kraak GJ (eds) Environmental fate and effects of pulp and paper mill effluents. St Lucie Press, Delray Beach, FL, p 69-78

Ford AT, Fernandes TF, Rider SA, Read PA, Robinson CD, Davies IM (2003) Reproduction in the amphipod, Echinogammarus marinus: a comparison between normal and intersex specimens. J Mar Biol Assoc UK (in press)

Glazier DS (2000) Is fatter fitter? Body storage and reproduction in ten populations of the freshwater amphipod Gammarus minus. Oecologia 122:335-345
Gray BR, Emery VL, Brandon DL, Wright RB, Duke BM, Farrar JD, \& Moore DW (1998) Selection of optimal measures of growth and reproduction for the sublethal Leptocheirus plumulosus sediment bioassay. Environ Toxicol Chem 17: 2288-2297

Ingersoll CG, Brunsen EL, Dwyer FJ, Hardesty DK, Kemble NE (1998) Use of sublethal endpoints in sediment toxicity tests with the amphipod Hyalella azteca. Environ Toxicol Chem 17:1508-1523

Lawrence AJ, Poulter C (2001) Impact of copper, pentachlorophenol and benzo[a]pyrene on the swimming efficiency and embryogenesis of the amphipod Chaetogammarus marinus. Mar Ecol Prog Ser 223:213-223

Lincoln JL (1979) British marine Amphipoda: Gammaridea. British Natural History Museum, London

Malbouisson JFC, Young TWK, Bark AW (1995) Use of feeding rate and re-pairing of precopulatory Gammerus pulex to assess toxicity of gamma-hexachlorocyclohexane (Lindane). Chemosphere 30:1573-1583

McLusky DS, Martins T (1998) Long-term study of an estuarine mudflat subjected to petro-chemical discharges. Mar Pollut Bull 36:791-798

Nelson MK, Brunsen EL (1995) Postembryonic growth and development of Hyalella azteca in laboratory cultures and contaminated sediments. Chemosphere 31:3129-3140

Roddie BT, Thain JE (2002) Biological effects of contaminants: Corophium sp. sediment bioassay and toxicity test. ICES Tech Mar Environ Sci 28

SEPA (Scottish Environment Protection Agency) (2000) Inverkeithing Bay sediment quality. Report TW 2/00

Sheader M, Chia FS (1970) Development, fecundity and brooding behaviour of the amphipod, Marinogammarus obtusatus. J Mar Biol Assoc UK 50:1079-1099

Skadsheim A (1984) Coexistence and reproduction adaptations of amphipods: the role of environmental heterogeneity. Oikos 43:94-103

SPSS (2001) SPSS advanced statistics 10.0. SPSS, Chicago, IL

Sundelin B (1983) Effects of cadmium on Pontoporeia affinis (Crustacea: Amphipoda) in laboratory soft-bottom microcosms. Mar Biol 74:203-212

Sundelin B (1984) Single and combined effects of lead and cadmium on Pontoporeia affinis (Crustacea: Amphipoda) in laboratory soft-bottom microcosms. In: Persoone G, Jaspers E, Claus C (eds) Ecotoxicological testing for the marine environment, Vol 2. State University of Ghent and Institute of Marine Scientific Research, Bredene, Belgium

Sundelin B (1988) Effects of sulphate pulp mill effluents on soft-bottom organisms - a microcosm study. Water Sci Technol 20:175-177

Sundelin B (1989) Ecological effect assessment of pollutants using Baltic benthic organisms. Dissertation, Stockhom University

Sundelin B, Eriksson AK (1998) Malformations in embryos of the deposit-feeding amphipod Monoporeia affinis in the Baltic Sea. Mar Ecol Prog Ser 171:165-180

USEPA (US Environmental Protection Agency) (1994) Methods for assessing the toxicity of sediment-associated contaminants with estuarine and marine amphipods. EPA 600/R-94/025. Office of Research and Development, US Environmental Protection Agency, Narragansett, RI

Zulkosky AM, Ferguson PL, McElroy AE (2002) Effects of sewage-impacted sediment on reproduction in the benthic crustacean Leptocheirus plumulosus. Mar Environ Res 54: $615-619$

Submitted: March 11, 2003; Accepted: September 23, 2003

Proofs received from author(s): December 8, 2003 